\title{
4
}

\section{Ontological conditions for non-evil}

\author{
Michael Heyns
}

Department of Philosophy

Potchefstroom University for CHE

POTCHEFSTROOM

E-mail: filmfh@puknet.puk.ac.za

Abstract

Ontological conditions for non-evil

In this article three interlocking ontological prerequisites for a condition of non-evil are identified. The first is the idea of a plurality of human aspects and dimensions that give one another room to exist, instead of an oppressing reduction to one aspect only. Secondly, these aspects need to exist next to one another as equally valued. This condition implies that even if a person lacks some aspect, she can still be affirmed as a human being because her humanity does not depend entirely or even mainly on the superiority of the missing aspect. Equality is, however, often interpreted as a homogenisation of all dimensions of life to one aspect only. This monism is a denial of variety and will only evoke its anti-pole in the form of a disengaged dualism or pluralism. I therefore argue that a third condition for the manifestation of a condition of non-evil is engagement between the aspects and dimensions of human life.

\section{Opsomming}

Ontologiese voorwaardes vir nie-boosheid

In hierdie artikel word drie aaneensluitende ontologiese voorwaardes vir 'n toestand van nie-kwaad geïdentifiseer. Die eerste is die idee van 'n pluraliteit van menslike aspekte en dimensies wat aan mekaar ruimte gun om te bestaan in plaas van ' $n$ verdrukkende reduksie van lewe tot net een aspek. Tweedens, hierdie aspekte behoort gelykwaardig te bestaan. Dit beteken dat selfs as 'n persoon een van hierdie aspekte kortkom, sy steeds as mens beskou kan word, want haar menslikheid is nie totaal of selfs hoofsaaklik afhanklik van die superioriteit van hierdie een aspek nie. Maar gelykheid word baie keer geïnterpreteer asof dit 'n homogenisering van alle lewensdimensies tot slegs een aspek beteken. So 'n monisme is 'n ontkenning van die verskeidenheid en sal slegs die teenoorgestelde in die vorm van 'n gefragmenteede dualisme of pluralisme ontlok. Die artikel sluit daarom af met die gedagte dat 'n derde voorwaarde vir die manifestering van 'n toestand van nie-kwaad 'n verbinding of samehang is tussen die verskillende aspekte en dimensies van menslike lewe. 


\section{Introduction}

The manifestation of evil in the twentieth century is a legacy without a testament, Buijs and Woldring state (2001:7-8)1. The absence of a testament refers to the astonishment when the nineteenth-century and early twentieth-century hope for a moral perfection of humanity did not materialise. In fact, the moral history of the twentieth century became the scene of the revival of evil in extreme forms; it is a legacy that was not expected. The early twenty first century repeated this experience when, after the end of the Cold War, the events of 11 September 2001 in New York and Washington (when fanatic Muslims hijacked three passenger planes and crashed them into the World Trade Centre and the Pentagon) caused a chilling reminder of the atmosphere of evil during the days of the Second World War and the Cold War.

The events of $9 / 11$ especially reminded us that religious fanaticism can be a source of evil. The fanaticist undertones in the so-called war against terrorism that followed did not do much to exonerate Anglo-American Christianity and Judaism from the burden of being sources of evil either. We also remember the bloody histories - in the name of Christianity - of the Crusades, Inquisition, religious wars, and colonialism. It is therefore not strange that the naturalist traditions of modernism and postmodernism accuse ontologies with metaphysical and religious roots of being sources for wickedness. But this is only part of the story because the flaw that leads to fanaticism is by far not restricted to religious and metaphysical traditions only, as the evil of secular exponents like Nazism, Stalinism, Pol Pot and others so vividly remind us. In fact, Buijs and Woldring (2001:10-12) point out that for the majority of continental political philosophers the focus of thinking is still the experience of these totalitarian regimes with their unprecedented oppression and masscruelty.

Of course, all these examples stand in stark contrast to the claims of religious and naturalist traditions about the importance of respecting and enhancing the life of fellow human beings. Contemporary life is thoroughly imbued by these traditions with their opposition to all kinds of wickedness (i.e. the evil that humans do$^{2}$ ). In fact, we can even speak of a contemporary ethos of anti-wickedness, which is the direct opposite

1 They repeat a seminal idea of Hannah Arendt.

2 In this respect I rely on the traditional division between moral evil or wickedness that arises "from the inhumanity or the culpable incompetence of mankind", and the nonmoral evil of suffering or pain "that are entirely independent of the human will" (Hick, 1973:38-40). 
reaction to the oppressing and terrorising violence and counter-violence associated with the fanatic developments of the twentieth century.

What then is the nature of the lapses of religious as well as secular traditions into episodes of evil? (This ontological way of formulating the question is not precisely the same as the more psychological and theological question about the causes of these lapses.) The question about the nature of evil can also be put from another more general and positive angle: What are the ontological conditions that will limit the influence of wickedness on our world?

In my attempt to answer this question, I will depart from the old Christian dictum that evil is the perversion or deformation of an original good creation. 3 To be more specific: In opposition to the totalitarianism that spells the core of the twentieth-century experience of evil, 4 I will argue 5 that human wickedness ensues from those human actions and directions that oppose, suppress, and attempt to kill life as a rich diversity. In this attempt I will argue that specifically the non-recognition of the plurality of creation, the non-recognition of the equality of this plurality, as well as the non-recognition of the need for this plurality to be inter-connected, will prepare the way for evil actions to arise.

\section{Plurality}

\subsection{Modern naturalism}

In a well-known part of his Dialogues concerning natural religion, David Hume (1947:205-210) gives an explanation of four interlocking "circumstances" on which all ills of the world and our life in it depend. It is particularly the third and the fourth "circumstance" that interest me. The Christian assumption about evil as the deformation/perversion of the good creation, is related to his fourth circumstance for non-evil, that is that the "parts of the universe" should "hang all together". Evil arises, he says, when some parts of the universe do not "keep precisely within those bounds in which their utility consists"; that is when they "run into

3 This view is rooted in the "classic Christian teaching, first developed by Augustine, that evil represents the going wrong of something that in itself is good" (Hick, 1973:37). From particularly a Christian-Reformational perspective Marshall (1998:32) describes the deformation of creation as follows: "Sin distorts everything, perverts everything, corrupts everything. Sin lives off that which is good. It is a parasite, feeding greedily on the goodness of what God has made."

$4 \quad$ As Buijs and Woldring (2001:10-12) argues.

As Peck (1990:46-47) also suggests.

Koers 68(2 \& 3) 2003:217-235 
the one extreme or the other". For instance, the "greatest convulsions in society" occur when the "passions of the mind, ambition, vanity, love, anger", which in themselves are useful, break their limits. With this view Hume is in the vicinity of one of the most important conditions for evil to arise, namely the obsession with some part of creation and the consequential suppression or even death of the non-obsessed parts. Paradoxically he does not try to evade this condition for evil when he appoints the mind and related faculties as the ultimate source for human life. The third condition for non-evil is his observation that "reason and sagacity" is our "chief excellency" because we lack the bodily advantages that animals have for survival. But then it happens that people fall short of the rational capacity; that they do not excel in a "vigorous spring and activity of mind" and with it a "propensity to industry and labour" and that therefore only "the most violent necessity can oblige ... [them] ... to labour". Hume, of course, saw no contradiction between his fourth and third conditions for evil because the structure of reality is probably for him a rational structure which means that faculties other than the rational should take a lesser or subordinate position, which consequently then constitutes their proper position.

It is under the third condition for evil that Hume (1947:219-226) also categorises what he calls superstitious and enthusiastic religion. Fanaticism abounds with "pernicious consequences on public affairs" like factions, war, persecutions, oppression and so on. He therefore thinks that true religion should distinguish itself in three ways: It should first and foremost be rational, secondly, promote a temperate style and, thirdly, be a humane morality.

But can we, who live after the twentieth century with its scientific, technological, economic and administrative enhancement of cruelty, still maintain that emotion is mainly a menace, and that rationality will necessarily lead to non-cruel conduct? We live in (another) postrationalistic era and profess to have learned the evils of the obsession with (the various forms of) rationality. Should we not also acknowledge that we need other human faculties and values, like emotion and compassion, to inculcate non-cruelty? Hume's fourth circumstance for the development of evil indicates that emotions which overstep their boundaries seriously hamper the functioning of reason and thus lead to evil. It should, however, be added that a rationality which expands beyond its borders will produce the same result.

A recent theory about evil that shows some similarities with that of Hume is Garrard's (2002:321) attempt to define evil. For her, such a theory should give "some distinctive feature" for an act to be evil. More important, this theory should also include the state of mind of the evildoer 
because we "understand human action in terms of the reasons which the agents take there to be for acting". For it to be secular this theory should exclude any reference to something "trans-human" or something "metaphysical". Of course, a thoroughly naturalistic theory devoid of anything metaphysical will even resist any reference to the idea of an agent or his reasons and opt for a behaviouristic-like explanation of human acts. In the next section I will deal with Foucault who attempts just that. But this radical secularisation is not yet an option for Garrard. In fact, she expects the human ability to interpret situations to be the only guard against a world that recedes totally into evil. There is nothing "trans-human" to help us deal with evil in the same way as there is nothing "trans-human" that causes evil. This, of course, reminds of Hume's paradoxical reliance on an absolutised human reason to be the only shield against fanaticism.

Garrard's (2002:329-331) theory argues "that the evil act can be identified by reference to the reasons which the agent sees and fails to see, for acting". According to this, "the evil action is one in which the agent is entirely impervious - blind and deaf - to the presence of significant reasons ... for acting or refraining from action". For instance, to protect his child from dying from a disease, a person should spend money to heal the sick child. He can argue he wants to save money and not spend it on his sick child. This act will be evil because this reason for action (saving some money) means the person is blind for a significant reason (saving his child's life) for the appropriate action. Another example is that of the torturer who knows that he is causing appalling pain to his victim. He nevertheless proceeds with his torturing which means that he is in some way blind to the fact that "the pain which the victim is suffering is an overwhelmingly strong reason for him to desist". The evil person then suffers "from a profound cognitive defect - an inability to grasp the presence of reasons of the first importance".

Despite her secular obsession with the human ability of interpretation to resist evil, Garrard has the paradoxical intuition (very similar to Hume) that some deification of some part of reality prepares the way for evil to appear. If an obsession makes one blind to other reasons or aspects of reality for acting, it means that this obsession makes you blind to the variety in life and reasons this variety gives for other actions. In other words, the deformation of reality because of an absolutisation of some part of it and the suppression or elimination of other parts/reasons, is an important condition for evil to arise. This "anti-ism" suggests that, ontologically speaking, we need to start with the recognition of a plurality of human functions and dimensions of, and reasons for life to evade the evil of distorted actions. 


\subsection{Postmodern naturalism}

The suppression of the plurality in human life is not restricted to fanaticist religion and modern rationalism. In important respects, recent irrationalist naturalism (postmodernism) falls in the same category despite its muchgloated emphasis of pluralism. In the case of postmodernists the problem starts especially with the basic naturalist assumption, that is the denial of extra-natural or extra-material dimensions of reality. This too is a version of the suppression of the plurality of creation that paves the way for evil to emerge.

Postmodernist naturalists are of course not without their own ideas about the conditions for evil. They charge especially the spiritual ideals of modernism and Christianity of being merely a tool in maintaining oppression. According to Taylor (1989:70-71, 100, 519-520) the most prominent exponent of this form of naturalism was Nietzsche whose views are repeated in the postmodernism or neo-Nietzscheanism of Michel Foucault who saw some of the loftiest human goods as the cause "of untold misery and even savagery". Allegiance to higher goods supposedly leads to a "suppression of 'nature', and this introduces relations of domination within us" which is then "fatally reflected" in the relations between people. This is taken by neo-Nietzscheans as a refutation of these goods. But, for Taylor it is a "cardinal mistake" to believe that "a good must be invalid if it leads to suffering or destruction". Their argument fails to see that most moral positions are motivated by visions of the good. Naturalism wants us to lose the dimension that carries this appeal. Taylor, however, wants to be liberated from this naturalist stifling and mutilation of being human.

And indeed, naturalists in the end cannot maintain their reductionist view of reality if they attempt to resist the evil of oppression. A good example is Foucault's denial of the idea of a "sexual nature" for the human person. Foucault (1979:3-10, 106-107, 152, 154-155) attacks what he calls the "repressive hypothesis" in the popular discourse on sexual liberation. This hypothesis opposes an assumed repressive era or regime that tried to block the sexual nature from human life. But, Foucault argues, this "hypothesis" consists of a mere discourse (discursive practice/power) that produces the "idea of sex in itself", which is actually a grouping together, into an artificial essence, of "anatomical elements, biological functions, conducts, sensations, and pleasures".

Foucault (1979:150-152) anticipates that his rejection of this fictitious essence will cause some to accuse him that he only sees "phenomena that are variable ... secondary and ultimately superficial". Foucault (1979:157) meets this critique by affirming that we have "to counter the 
grips of power with the claims of bodies, pleasures, and knowledges, in their multiplicity and their possibility of resistance". He thus transposes the agent of resistance against the evil of oppression from the fictitious essence to "surface", or material phenomena like the body and expressions of desire, and rejects in this attempt what he sees as the metaphysical illusion of a sexual essence.

But, the counter-power of bodies raises the question whether Foucault really did get rid of all so-called metaphysical residues in the human being. Is the resistance of the body not the non-matter, agent-like behaviour that we usually associate with metaphysical essences like "sex-in-itself"? In other words, Foucault seems to have transposed resistance against evil from some fictitious essence in the deep inside of the human subject onto the body as its locality. 6 This move does not, strictly speaking, represent a return of essentialism in Foucault. However, some critics ${ }^{7}$ remark that Foucault needs something like an "essence" to promulgate effective arguments for non-oppressed life. These critics in other words highlight the absence of other dimensions to human life than the mere material as the weak point in Foucault's argument for liberation.

Another important postmodernist is more explicit about this need for a return of the non-material in our attempt to resist evil. According to Agnes Heller, 8 people like Hitler or Stalin did not choose themselves "as evil or wicked" because we live in a world where they "cannot tell good from evil". You can only make a personal choice to be evil "in a world where God is not yet dead" and where you are thus able to "choose yourself as an anti-Christ or as a demon or devil against the living God". But despite her affirmation of the death of God, Heller still believes that good can be measured by the maxim that "it is better to suffer rather than commit injustice". This means that she believes that "a lot of goodness is transcendent" and that even in our "modern ethic there is an absolute". But she is very quick to add that she "cannot really answer the question

6 Can we raise the same critique about this agentification of the body that Rorty (1993:33) has about Nietzsche's, namely that it appears to be a kind of "inverted Platonism"; that it reminds of "the romantic attempt to exalt the flesh over the spirit"? And indeed, Rorty (1993:64) thinks that despite Nietzsche's view "that the self, the human subject, is simply whatever acculturation makes of it, he still thinks in terms of something deep within human beings, which is deformed by acculturation".

7 Cf. e.g. the critique of Horowitz (1987:67-71), Dews (1989:38) and Lemert and Gillan (1982:105-106). 
why is the good person good" because this person is not "determined" to become good; his "determination is chosen by the good person himself". The reason we find it difficult to distinguish between good and evil, she says, is because of the perspectivism of our time: "there is no totality of all perspectives, as there is no mind that can encompass this" and therefore "we see only segments". She nevertheless denies that this should result in "a relativism or untruth" although it means "that there is an understanding that is also a misunderstanding" because the "centre is never hit because of this perspectivism".

Although her acknowledgement of the need for a return of the extranatural or the extra-material is very ambiguous and brittle in Heller, it is there and very important if we want to be good. In the current postmodernism there is thus probably a stronger sense that human life functions on and is influenced by more levels than would be acknowledged by these exponents of this kind of naturalism.

\section{Equality}

But the affirmation of structural plurality in human life as a condition for anti-cruelty should be enhanced with two other conditions. It should secondly have to be a plurality of capabilities and dimensions of equal value. Thirdly, this plurality of equally valued aspects of life should form a pattern of inter-connection in order to avert a fragmented pluralism, dualism or totalitarian monism. The rest of the article will be used to argue these two conditions.

\subsection{Anti-cruelty and our humanity}

From a Christian perspective one will have to move further than the mere recognition of the plurality in creation/life and the need to let this plurality flourish. Furthermore, we cannot rely only on the human abilities to reason and interpret to be the shield against evil. It is therefore significant to take note of prominent Canadian philosopher Charles Taylor's (1991d:245) identification of God as one of the main authors of morality. However, notwithstanding his reticent pronouncements about the presence of God, 9 Taylor attracts severe attacks from the secular corner. One such attack comes from Quentin Skinner (1991:147-150;1995:47) who argues that the impact of Christianity on humanity "was nothing less

9 Commentators like Lovin (1991:264) and Waldron (1990:325) remark that Taylor's argument represents a good example of the progress in contemporary Christian tolerance for non-christian views. 
than catastrophic".10 The recommendation to once again adopt Christianity thus seems to him like an instance of "offering a cure for our ills much worse than the disease". Skinner takes note of a suggestion by Taylor that atrocities in the name of Christianity are no reason to dismiss this religion in total. But, he says, Taylor's argument would be true only if he can assure us that the horrors committed in its name were "wholly unconnected with its character as a creed".

Part of the structural flaw that some naturalists see in Christianity pertains to the notorious dilemma in the theodicy problem. Rosen (1991:190-191) for instance confronts Taylor with the theodicy problem and argues that the notion of a cosmic order of divine origin contains a major inconsistency, namely that evil is incompatible with the concept of the world as the creation of "a single, benevolent deity". The main answer of Christianity is that evil is caused by human action; it is retribution for "Original Sin". This answer is given in order to avoid the heresy of Gnosticism that makes evil "a transcendent principle in its own right, in conflict with divine goodness". The critical question of Rosen about God's wrath against sin, namely, "is such unremitting and vicarious punishment really benevolent?", is also relevant to the question whether a cruel god who is the author of a cruel world will be able to instil a spirit of anti-cruelty in his followers.

Rosen's premise, namely that God's punishment is irreconcilable with anti-cruelty, ignores the point of especially the New Testament message of grace and the ethos of compassion this is supposed to evoke in the community of Christians. We can also point to the fact that one of the most important Christian ideals working in contemporary civilisation is a strong notion of human dignity 11 that strengthens our ethos of anticruelty. Taylor (1989:516-518; 1991b:241) also refers to it. He doubts whether naturalist secularism can give people dignity when humans are primarily seen as "rational, emancipated moderns". This view, Taylor says, will break down in the case of "the irremediably broken" like mentally handicapped people, terminally ill people and unborn children with genetic defects. Enlightenment naturalists will argue that "perhaps

10 This is a well-known complaint about Christianity. Cf. e.g. also Waldron (1990:326) and Bauman (1994:4-8).

11 Even an atheist and postmodern relativist like Richard Rorty (1991:192, 197, 199-202) acknowledges that human dignity is given in Western communities by the strong motive of the Judaeo-Christian religion that the stranger without dignity is to be taken in and given dignity again. Balslev (1991:48-49) remarks that Rorty's reference to the Judeao-Christian assumption "show[s] the inadequacy of the postmodernist bourgeois liberalism to support such a course of action without a meta-narrative". 
effort shouldn't be wasted on these unpromising cases". But, says Taylor, this is not the case for someone like Mother Teresa who argues from "a Christian spirituality". This is for Taylor an indication that "great as the power of naturalist sources might be, the potential of a certain theistic perspective is incomparably greater". For Taylor naturalist accounts are "inherently contestable in a way that the theistic outlook is not". He agrees that theism is "contested as to its truth", but "no one doubts that those who embrace it will find a fully adequate moral source in it". 12 For naturalist philosophers on the other hand, the problem is that even if everybody "fully recognize[s] the dignity of disengaged reason, or the goodness of nature", this is in fact not "enough to justify the importance we put on it, the moral store we set by it".

But this claim that Christianity is a more adequate source of goodness, is not acceptable to naturalists. Kymlicka (1991:181) is for example "not at all clear in what other (non-prudential) sense God provides an adequate moral source". Theists for instance put an embargo on scientific testing on human embryos because these embryos "bear the image of God". But Kymlica asks: "So what?" The image of God has "no obvious moral relevance". Qualities that have relevance are, for instance, the capacity to feel pain. Theists do not really explain why non-sentient human embryos deserve greater moral consideration than sentient animals. He foresees that theists will respond that he does not understand the full moral significance of being the image of God. But, says Kymlicka, he can say the same about a theist who fails to understand the full moral significance of rationality or sentience. His point is that there is "no sense in which the theist position is less 'inherently contestable'". 13

Kymlicka seems to suggest that it is acceptable to place human identity in a particular human capacity. This means that if our humanity and for that matter our human dignity, rests on sentience, reason, or any other human aspect or function, not all people will fully qualify for being human. Embryos, but also retarded human beings, will represent a subhuman species towards which we can act accordingly. However, to quote Taylor's, this is not the motivation of Mother Teresa. She will treat the non-sentient as fully human. Although Taylor does not spell this out, Mother Teresa's motivation has an important implication for our human

12 According to Lemmens $(1994: 125,131)$ and Shklar (1991:105), this point of view portrays his appreciation of the concept of divine grace as the absolute source of the good. I believe, however, that divine affirmation of the goodness of creation is a better way to describe that which motivates Taylor.

Others raise the same point. Cf. Schneewind (1991:426) and Larmore (1991:161). 
identity; this identity does not reside in any one of our aspects, functions, faculties, or dimensions. If it would have, it would have meant that if we lose it, we lose our full human identity. Thus, no aspect or dimension of being human is more human than the other - all of them are equal in the sense that not one of them can make us more human than another person. And this means that all human beings, despite differences of individual propensities, strengths and weaknesses, have equal dignity and deserve equal treatment and thus to be equally free from cruelty.

\subsection{The affirmation of creation}

Why should a Christian not treat a person who lacks certain abilities as subhuman? Kymlicka seems to miss the theistic point that if God calls you human, it means that even if you do not portray perfect human traits, you are still human. ${ }^{14}$ This seems ${ }^{15}$ to be Taylor's (1989:521) point with his hope to find the "promise of divine affirmation of the human" in "Judaeo-Christian theism". This, he says, assumes an affirmation of the human that is "more total than humans can ever attain unaided".

Taylor $(1989: 218,516)$ regards naturalism as "in part motivated by the sense that in rejecting religion it is for the first time doing justice to the innocence of natural desire". But this view implies for Taylor a parasitic attitude because "the original model" for the affirmation of nature is the connection between agape and the goodness of creation. In this respect we are dealing with the primordial divine affirmation of creation, which is given in the repeated phrase in Genesis 1 "and God saw that it was good". To love human beings or any other being is, according to Taylor, "inseparable from such a 'seeing-good"'. Taylor (1989:270) therefore argues that "sanctification" in the Judaeo-Christian tradition "does indeed involve embracing a higher morality". This higher morality is, however, "not defined only in terms of certain 'higher' activities, or love of the order of things" but by "an affirming of life". God affirms life and this is expressed in Christian thinking by the "key notion" of "agape, or charity,

14 On this point it is instructive to take note of the debate between two groups of Christians to which Evans (1993:100-102) refers. One group claims that the human being is a given entity. A second sees personhood as an accomplishment reached through activities; to be a person is to become. The second viewpoint, he says, is unfriendly to the Christian view because it disables an ethic that honours the humanity of disabled, insane, unborn and other frail people.

15 Klink (2002:78) finds Taylor's reference to "divine affirmation" unclear. It is thus clear that the idea that it refers to a "bestowment of a human identity" depends heavily on my own interpretation. 
God's affirming love for the world (John 3:16), which humans through receiving can then give in turn".

According to Taylor (1989:13-14), the affirmation of creation and the ethos among Christians this evokes in the form of the affirmation of ordinary life "has become one of the most powerful ideas in modern civilization".16 In fact, it influences our whole concept of what "it is truly to respect human life and integrity". This influence is created especially through one of the offsprings of the affirmation of ordinary life, that is the "practical benevolence" or the importance we put on avoiding suffering. 17 According to Taylor $(1989: 12-13,84-85,258)$ the notion of benevolence has become a central aspect of secular Enlightenment morality;18 we are much more sensitive to suffering than our forebears. Important for my argument in this respect is that Taylor thinks that a major part of the explanation for this sensitivity to cruelty is that the idea of a hierarchical cosmic moral order, which gives sense to the idea that people should be punished if they do not know their proper place, has faded. This fading of hierarchy happened because of the influence of the affirmation of ordinary life.

According to Taylor (1981:112-114; 1989:13-14 ,23, 81, 83, 211-213, $215,218,235)$ the pre-modern era made a strict hierarchical distinction (i.e. dualism) between ordinary life (i.e. especially the life of production and reproduction, of work and the family) and the elitist, aristocratic values of contemplation and citizenship. Ordinary life is a life absorbed in meeting life-needs and the destiny of the majority of people. This

16 Some critics doubt whether Taylor's account of the pervasive influence of ordinary life is correct. Skinner (1991:140-142; 1995:41-42) for instance, argues that labour and family life do not have the value they used to have. Taylor (1991b:237-239) answers that the affirmation of ordinary life indeed transmutes, but that it maintains "a certain continuity" with its starting point in sixteenth-century Protestantism. The current belief that self-fulfilment culminates in sex is, for instance, such a continuance. This, he says, "would horrify the Puritan divines of yesteryear". Nevertheless, the "continuity is there, and ... illuminates".

17 That the avoidance of pain is probably the strongest moral motive currently at work in Western civilisation is also affirmed by Rorty (1993:xiv-xvi, 73-75, 146).

18 Williams (1990:47) objects to the notion that this motive has been activated by Christianity. In fact, he thinks the modern liberal sense of benevolence has been resisted by Christianity. For instance, Christianity, though it was an "official" religion since the fourth century, did not do much to prohibit slavery. Taylor's claim, Williams says, seems "either not obvious at all, or else so weak that it does not offer much to the self-understanding of modern liberalism". Taylor would (as with similar arguments against his vision) probably retort that Williams fails to see the continuance between Christian benevolence and latter-day secular mutations. 
dualistic and hierarchical concept was justified by the ancient concept of a hierarchical cosmic logos. According to Taylor it was the thinkers of the Reformation who made a difference when they hallowed ordinary life. The important issue for the Reformation, says Taylor, was how human life is led; "whether worshipfully and in the fear of God or not". This motive has engendered a rejection of the claims made on behalf of the earlier elitist moral motives that excluded the "ordinary" goals and activities" of human life. This view also implied that the idea of a hierarchical chain of being was rejected. Taylor thinks this was a good development but he also points out that the affirmation of ordinary life gradually secularised and that its naturalist version wanted to "denounce all qualitative distinctions" for being "blind to the dignity and worth of ordinary human desire and fulfilment". The idea of a life "according to nature" meant that the satisfaction of biological needs became a moral obligation in itself. This prepared the way to see the need "to be rightly placed in relation to the good" as a source of "suffering" or "self-delusion" or "smug self-satisfaction". This naturalist version of an original Christian motive had the ironic effect that especially Christian "higher" moral ideals have been attacked since the Enlightenment "for laying a crushing burden on those in whom it inculcates a sense of sin".

The affirmation of ordinary life as Taylor describes it, is indeed an important correction to the dualistic and hierarchical elitist morality of premodernism because it emphasises parts of life that had previously been ignored. Hart (1984:312-313) points out that the "deepest origin of dualism" is to be found in "a fundamental misinterpretation" of the "fundamental opposition between good and evil" which is a dualism of direction; you either move in the direction of the good or not. When we project evil on some aspect of life, we distortively reify evil by making this part the origin and carrier of evil. But this approach is to deny the fundamental goodness and thus equality of all aspects of life.

However, the fact that secularism uses this emphasis on equality against Christianity should signal to us that everything is not well with what Taylor describes as the affirmation of ordinary life. This principle should give an alternative to the impression that Christianity can only envision a hierarchical life dominated by some metaphysical or idealistic world. Idealism gives, as in the case of Platonism and neo-Platonism, reason to denigrate the non-idealistic or non-metaphysical as lower in rank and to oppress it. But it is not only Christianity that struggles with the cruelty of totalitarian and hierarchical visions. An important point that Taylor should have made is that the secular emphasis on nature and desire is actually a rejection of the levelling effect of the affirmation of ordinary life. It implies that nature and desire become more ordinary than any other mode of living. This is not too far from introducing a new elitist motive 
and thus a new hierarchy, a new dualism, and probably new forms of suffering.

This ontological fallacy is already visible in Taylor's description of the affirmation of ordinary life. Although he wants to be more comprehensive in what he acknowledges, he too steps into the trap of over-emphasising only certain aspects of creation. Taylor gives a very particular content to ordinary life: the life of production and reproduction. This, to once again use a common platitude, signals aspects of life that are more equal than others, that is, strictly speaking, against the spirit of the affirmation of ordinary life. This view, it seems to me, excludes a whole array of things that are also part of life. For instance, what about the life of leisure, aesthetics, maintenance, politics, religion, and so on? It should be acknowledged that the affirmation of the concept of ordinary life opened the way for the acknowledgement of the equality of the various human aspects which is an important condition for the existence of a full human life or a non-oppressed variety of human aspects. But it is important to be careful about what is included in the definition of ordinary life. It should not be a new reduction of the plurality of human aspects and dimensions of life; in fact all aspects of life should qualify for inclusion in "ordinary" life.

\section{A coherent human life}

I have argued thus far for a plurality of equally valued aspects and dimensions of reality and particularly of human life to enhance an ethos of anti-wickedness. But we also need to focus on the inter-relatedness and inter-connections between these aspects and dimensions in order to clear the way for a world of less evil.

The affirmation of ordinary life opens room in Christianity (more precisely reformational Christianity ${ }^{19}$ ) for a process of secularisation that gives a greater appreciation for this life which softens the disengagement inherent to a severe secular-transcendent dualism. Taylor (1989:5-7, 16$17,26 ; 1991 \mathrm{a}: 3)$ also acknowledges the inevitability of secularisation. He describes it as a demise of the ancient idea of the "cosmic order". The cosmic order, he says, had been seen in ancient times as a hierarchy in which everything was tied to a "proper place" even if it meant a situation

19 Cf. the following conclusion of Marshall after his struggle with the image of an evangelical Christianity that sees most aspects of ordinary life on earth to be part of the kingdom of sin or at least not part of God's kingdom. He (Marshall, 1998:11) emphasises that "[o]ur destiny is an earthly one: a new earth, an earth redeemed and transfigured". It is therefore "an unbiblical idea that the earth doesn't matter because we are going to go to heaven when we die". 
of oppression. Although he does not want to go back to some premodern phase, Taylor (1991a:2-4; 1989:507) is nevertheless "ambivalent" about the disenchanted condition. Cosmic orders not only retricted people, they also "gave meaning to the world and the activities of social life". The loss of this purpose resulted in a flattening of life because people focused on their individual lives; this attitude caused "a centring on the self" which made our lives "poorer in meaning, and less concerned with others".20

Thus, Taylor, contradistinctively to postmodern naturalists like Foucault, senses that we need to save a multidimensional perspective in order to escape the flattening of life caused by a relentless homogenisation or one-dimensionalisation of reality. But homogenization is the misguided expression of the sense that the dimensions of reality need to interact. We therefore need to add a third condition to our efforts to envision a reality that makes evil difficult to appear, that is that the structural variety should form a connected/engaged plurality and not a disengaged or fragmented pluralism.

Pluralism assumes that engagement is a scarce commodity in our world where the various dimensions, aspects, and basic principles constantly overstep their boundaries and thus set the scene for the large amount of conflict and suffering that we experience. Berlin (1969:167-168) for instance observes that the belief that values like liberty, justice, generosity, loyalty and equality are perfectly compatible with one another is a fictitious metaphysical notion. He believes we can offer nothing more than the empirical observation that these values in many instances contradict one another because they make ultimate and absolute claims on human life. Does this mean that we have to accept that important ingredients of human life like liberty and equality should be omitted because they often contradict each other? But this will spell an acceptance of a condition conducive to evil. The fact that Berlin tries to affirm the importance of all goods while limiting the choice among them because of their empirical state of agonism, implies that he cannot escape the underlying wish ("idea") that they would be reconcilable. This becomes even more probable when one takes into account that what Berlin (1969:170-171) actually criticises, is not reconciliation as such, but the reduction of all values to a single exalted one (i.e. monism) and the deformation of human life as the result of this monism. The point of mentioning pluralist reactions is that the need for connectedness between aspects often manifests in a reduction of all aspects/dimensions 
of life to only one of them (i.e. monism). To portray this equalisation or homogenisation as unity is, however, not an expression of engagement but a denial or suppression of, and thus disengagement from some aspects. It is therefore important to dwell briefly on this homogenisation that makes an integrated view of reality and life impossible.

In the place of monism we need an ontology that confesses for instance a coherent but nevertheless tripartite distinction between God, and the dimensions of firstly the motives/norms controlling our lives, and secondly, the human subjects in the grips of this order. In fact, I think it is crucial to make these distinctions while not losing the perspective on their coherence. A monism that emphasises only the coherence will inevitably evokes its antithesis in the form of dualism and pluralism. One such monism relevant to my argument is pantheism. Pantheism is a reduction of reality to only God and a suppression of, and disengagement from the other two dimensions. Troost (1994:3-6,8-11) points out that the idea of a divine order was very much part of all ancient world religions. Important about this phenomenon was its inherent pantheism; the creature was seen as participating in the divine nature. With the origin of science and philosophy, however, a pagan anti-pantheism set in. In place of a divine world order, a belief in the "logos" arose. This logos-idea entered Christianity because Christianity too was sceptical about the idea of pantheism. But this was a fatal step (for Christianity) because the secularist view of nature was also accepted. This view was of a "desacralised" creational order and was therefore seen as something "self-existent". A disengagement between God and reality/daily existence was created that lead to the pre-naturalist phenomenon of deism (or natural religion).

A modern manifestation of this dualism (disengagement) is found in the marginalisation of religion to a so-called private sphere. In his critique of Taylor, Vogel (1993:332) for instance argues that the reason for the disenchantment of the universe is that religion "ultimately rest[s] on intuition or faith and so cannot be validated as knowledge within the realm of public argumentation". Therefore, any view of the good that depends on religion is regarded as dogmatic to the contemporary mind and the imposition of religious ideas in the public domain is regarded as "the equivalent of religious warfare". Taylor (1989:342) however, does not want to be a deist and chooses for moral sources that "involve God" because these sources present to him the "most illusion-free" sources. Taylor therefore seemingly wants to evade the trajectory that leads from a stance of anti-pantheism to dualistic deism to full-blown monistic naturalism. 
Deism, because of the fear for religious warfare, is an example of a disengaging reaction to pantheism. But it is not only deism that is the victim of the disengagement evoked by the monistic paradigm of pantheism. As explained earlier, Foucault for instance, reacted so severely against the dualism which essentialism causes, that he entangles himself in the incoherences of seeing everything as simply "superficial natural phenomena" (i.e. naturalism). Moreover, pluralism, as the manifestation of the disconnectedness between the plurality, is also the captive of the aspirations of monism; pluralism is the overemphasised wish of the plurality to be affirmed.

Pluralism, monism and dualism should thus be replaced by a paradigm of engagement. This, I believe, is only possible within the perspective of the cohering influence of the radically different Transcendent via His cosmological order. This perspective translates into a call for a creative and reformative zeal among Christians to preserve and deploy the structural variety of creation, to affirm the basic value equality of all parts of creation, but also constantly to seek avenues to keep this variety connected. This, in fact, should spell the basic structure of any strategy to avoid evil and its offspring, cruelty.

\section{Bibliography}

BALSLEV, A.N. 1991. Cultural otherness: correspondence with Richard Rorty. Shimla : Indian Institute of Advanced Study (in collaboration with New Delhi : Munshiram Manoharlal).

BAUMAN, Z. 1994. Postmodern ethics. Oxford : Blackwell.

BERLIN, I. 1969. Four essays on liberty. London : Oxford University Press.

BUIJS, G.J. \& WOLDRING, H.E.S. 2001. De erfenis van het kwaad. (In Buijs G.J. \& Woldring, H.E.S., reds. Grote politieke denkers: hun strijd tussen goed en kwaad. Zoetermeer : Meinema. p. 7-15.)

DESCOMBES, V. 1994. Is there a politics of authenticity? Raritan, 13:102-123.

DEWS, P. 1989. The return of the subject in late Foucault. Radical Philosophy, 51:37-41.

EVANS, C.S. 1993. Human persons as substantial achievers. Philosophia Reformata, 58(2):100-112.

FOUCAULT, M. 1979. The history of sexuality. Volume 1. An introduction. London : Lane.

GARRARD, E. 2002. Evil as an explanatory concept. The Monist, 85(2):320-336.

HART, H. 1984. Understanding our world: an integral ontology. Lanham : University Press of America.

HICK, J. 1973. Philosophy of religion. Englewood Cliffs, N.J. : Prentice-Hall.

HOROWITZ, G. 1987. The Foucaultian impasse: no sex, no self, no revolution. Political Theory, 15(1):61-80.

HUME, D. 1947. Hume's dialogues concerning natural religion. (Edited with an introduction by N. K. Smith.) London : Nelson.

KLINK, A. 2002. Goed, kwaad en de affirmatie van het leven. Philosophia Reformata, 67(1):65-79.

KYMLICKA, W. 1991. The ethics of inarticulacy. Inquiry, 34(2):155-182. 
LARMORE, C. 1991. Review of 'Sources of the self' . Ethics, 102(1):158-162.

LEMERT, C.C. \& GILLAN, G. 1982. Michel Foucault: social theory and transgression. New York : Columbia University Press.

LEMMENS, W. 1994. Zelf en gemeenschap: de paradox van die moderne identiteit volgens Charles Taylor. Tijdschrift voor Filosofie, 56(1):117-133.

LOVIN, R.W. 1991. Inescapable frameworks of meaning. The Christian Century, 108(8):263-265, March.

MARSHALL, P. (with Lela Gilbert). 1998. Heaven is not my home. Nashville : Word Publishing.

MORGAN, M.L. 1995. Religion, history and moral discourse. (In Tully, J. \& Weinstock, D.M., eds. Philosophy in an age of pluralism: the philosophy of Charles Taylor in question. Cambridge : Cambridge University Press. p. 49-66.)

PECK, M.S. 1990. People of the lie: the hope for healing human evil. London : Arrow Books.

RORTY, R. 1991. Objectivity, relativism, and truth: philosophical papers. Volume 1. Cambridge : Cambridge University Press.

RORTY, R. 1993. Contingency, irony, and solidarity. Cambridge : Cambridge University Press.

ROSEN, M. 1991. Must we return to moral realism? Inquiry, 34(2):183-194.

RUNDELL, J. 2000. The postmodern ethical condition: a conversation with Agnes Heller. Critical Horizons, 1(1):135-145.

SCNEEWIND, J.B. 1991. Review of 'Sources of the self'. The Journal of Philosophy, 88:422-426.

SHKLAR, J.N. 1991. Review of 'Sources of the self' . Political Theory, 19(1):105-109.

SKINNER, Q. 1991. Who are 'we'? Ambiguities of the modern self. Inquiry, 34(2):133-153.

SKINNER, Q. 1995. Modernity and disenchantment: some historical reflections. (In Tully, J. \& Weinstock, D.M., eds. Philosophy in an age of pluralism: the philosophy of Charles Taylor in question. Cambridge : Cambridge University Press. p. 37-48.)

TAYLOR, C. 1981. Growth, legitimacy and the modern identity. Praxis International, 1:111-125.

TAYLOR, C. 1989. Sources of the self: the making of the modern identity. Cambridge : Cambridge University Press.

TAYLOR, C. 1991a. The malaise of modernity. Concord, Ontario : Anansi.

TAYLOR, C. 1991b. Comments and replies. Inquiry, 34:237-254.

TROOST, A. 1994. The idea of creation order in Western thought. Institute for Reformational Studies Study-pamphlets, 324:2-16.

VOGEL, L. 1993. Review of 'The ethics of authenticity and multiculturalism and the politics of recognition'. International Journal of Philosophical Studies, 1(2):325335.

WALDRON, J. 1990. How we learn to be good. The Times Literary Supplement: 2329, March.

WILLIAMS, B. 1990. Republican and Galilean. The New York Review: 45-48, November 8.

\section{Key concepts:}

evil and cruelty

human dimensions: plurality, equality, coherence

wickedness 


\section{Kernbegrippe:}

boosheid

menslike dimensies: pluraliteit, gelykheid en samehang wreedheid 
